\title{
Ricoeur's Philosophy of Imagination
}

\author{
George H. Taylor
}

In her foreword to the French translation of Paul Ricoeur's Lectures on Ideology and Utopia, Myriam Revault d'Allonnes maintains that if there is one philosophical problem that pervades a number of Ricoeur's inquiries, it is that of imagination. ${ }^{1}$ I agree. Yet in Ricoeur's published work we find only scattered references to this topic ${ }^{2}$ and no comprehensive development on this subject so apparently central to his thinking. My claim is that scholarly attention to Ricoeur's unpublished "Lectures on Imagination" may redress this lacuna in his work. ${ }^{3}$ These Lectures provide the only place where we find a more complete structural framework of Ricoeur's argument as it moves from an analysis of reproductive to productive imagination.

My comments are based on a transcription of Ricoeur's Lectures, which were delivered at the University of Chicago in the fall of 1975. These Lectures came at a critical cusp in Ricoeur's career. Ricoeur's other set of lectures that term were the ones on ideology and utopia that I later edited for publication. ${ }^{4}$ Ricoeur's book on metaphor, La métaphore vive, ${ }^{5}$ had just been published, and elements of that work are revived in the Lectures. Late in the Lectures his subsequent work on narrative is also foreshadowed. At this central juncture, Ricoeur is crystallizing his thoughts on poetics (and so fulfilling in a recast way the third part of his Philosophy of the Will). ${ }^{6}$ Imagination lies at the heart of his thinking at this time.

Let me sketch where Ricoeur is headed in the "Lectures on Imagination" and then provide a sense of the steps he takes to get there. I'll end with some general thoughts on his theory. Ricoeur is driving toward the development of a theory of productive imagination 
as opposed to one of reproductive imagination, and he maintains that there are four domains of productive imagination. ${ }^{7}$ First, within the domain of social and cultural imagination, utopia is the fiction that exemplifies productive imagination. The dialectic between utopia and ideology - ideology being reproductive social imagination - was the subject of his separate lectures on that topic. Part of the great fascination, then, of hearing both sets of lectures was the commonality between them of the theme of imagination. Ricoeur adverts to utopia at points in the imagination lectures as well. The second and third domains of productive imagination are epistemological imagination and poetic imagination, and both are principal subjects in the imagination lectures. The fourth domain is that of religious symbols and is treated elsewhere in Ricoeur's corpus. ${ }^{8}$

Part of Ricoeur's central goal in the imagination lectures is to demonstrate that imagination is not something marginal to or occasional in thought but rather permeates all thought and conceptualization. We have learned, says Ricoeur, from both the psychology of perception and ordinary language philosophy that there is no such thing as a brute impression, an impression that is direct and unadorned by human structuring. ${ }^{9}$ Instead, perception is always structured by physiological and imaginative processes. Citing Kant, Ricoeur contends that the "imagination is not at all an alternative to perception [as it is in Hume] but [is] an ingredient of perception. It's encapsulated within the framework of perception." ${ }^{10}$ Elsewhere in these materials Ricoeur argues that " $[\mathrm{w}]$ e can no longer oppose ... imagining to seeing, if seeing is itself a way of imagining, interpreting, or thinking." 11

In the Lectures, Ricoeur challenges the history of Western thought not only in its general failure to comprehend the interrelation of imagination and seeing but also in its almost singular emphasis aside from Aristotle and Kant, to whom I will return - on the reproductive imagination to the exclusion of the productive imagination. The first two major sections of the Lectures are devoted to this exploration and criticism of the role reproductive imagination has played in major classical and contemporary figures in Western thought. Part of the power of Ricoeur's work here, as throughout his corpus, is that his philosophy is not insular, talking only with those who are like-minded, but is willing to address, incorporate, but also demonstrate the insufficiency of other fields. Just as in his earlier attention to Freud ${ }^{12}$ or to structuralism ${ }^{13}$ where Ricoeur analyzed these fields according to their own terms and then showed the space they allowed for his own 


\section{RICOEUR'S PHILOSOPHY OF IMAGINATION}

hermeneutics, in the imagination lectures Ricoeur takes on, for example, psychology and analytic philosophy and argues that their attention to reproductive imagination still leaves space for productive imagination. A continuing question he pursues in the Lectures is whether fields such as analytic philosophy are able to address adequately human creativity. ${ }^{14}$

Let me survey Ricoeur's development of the history of reproductive imagination in the West to set the stage for what he promotes by contrast in the productive imagination. Dating back to Plato, the character of the imagination has typically been subsumed under study of what it is to have an image, an image, supposedly in the mind's eye, of reality. The rationalist Plato will distinguish images from the true concepts that lie in the Ideas, the Forms,${ }^{15}$ while the empiricist Hume will seek to understand the movement from sensory impressions to images to the association of images that provide concepts. ${ }^{16}$ For Spinoza the imagination is equivalent to inadequation: illusion, prejudice, something lacking. ${ }^{17}$ For religious Pascal, imagination is sophistry, deception. ${ }^{18}$ Even as twentieth century philosophy of logic turned away from the image to concentrate on the logic of the proposition, ${ }^{19}$ the image remained the subject of discussion in the philosophy of mind. ${ }^{20}$ Ryle dismissed the existence of the image $e^{21}$ - the mind was the proverbial ghost in the machine ${ }^{22}$ - while others, such as the little known H.H. Price, considered what it meant to think in or through images. ${ }^{23}$ In each case where the image was discussed, there was a distinction between an original - reality - and a copy - the image or the imagination, and in each case, the copy was always less than the original. ${ }^{24}$

For Ricoeur, this model of original and copy exemplifies reproductive imagination. The image as copy is at best derivative from the original - from reality. At worst, to the degree the imagination tries to portray something different from the original, it is simply marginal, an escape or flight from reality; it produces nothingness. ${ }^{25}$ The history of Western thought - again with the principal exceptions of Aristotle and Kant - is one of attention to reproductive imagination only. Two more contemporary examples provide additional clarifications of Ricoeur's point. Although his work does not regard the image but language use, Wittgenstein is the subject of one lecture. Ricoeur finds provocative in Wittgenstein the interchange, so important for Ricoeur, between language and seeing. Our language may be well-adapted to deal with objects, but it does not encompass so well how the mind "sees" pictures such as the famous duck-rabbit, where we view the 
same sketch alternatively as that of a duck or that of a rabbit. ${ }^{26}$ Our reports of these experiences "constitute a struggle with words," and the task, says Wittgenstein, is to rework the report, which interestingly goes beyond acceptance of meaning as use. ${ }^{27}$ But this fight between seeing and thinking ${ }^{28}$ in Wittgenstein remains at the level of reproduction. In the pictures such as the duck/rabbit, Ricoeur claims, "there is nothing productive." 29

A second contemporary example lies in Sartre's psychology of the imagination. For Sartre, "the imagination is the necessary condition for [human] freedom'." 30 Sartre locates freedom through a theory of "nothingness," that is, of the unreal, that which escapes from the boundaries of current empirical reality. As we shall see, Ricoeur wants to build on Sartre's theory of the unreal to develop his own approach to productive imagination, but Ricoeur finds a fatal limitation in Sartre's theory. Sartre illustrates the ability of human thought to have an image of the unreal on the basis of an image of someone absent, his friend Peter in Berlin. But this image is itself reproductive, because it is an analogue of an original, the real Peter. ${ }^{31}$ Absence is conceived as "paradigmatic for nothingness," 32 but this reduces it to the theory of nothingness. "Presence and absence are distinctions relative to [current empirical] reality." 34 Absence is a copy - a form of reproductive imagination - of someone present.

With this welter of emphases in Western thought on reproductive imagination, how then does Ricoeur propose by contrast to establish productive imagination? He probes whether we can conceive of a place that, unlike an image, is not duplicative of, not determined by, an original. Perhaps the easiest example to comprehend is the social utopia. The literal translation of utopia is a "nowhere." ${ }^{35}$ The utopia is "the possibility of [the] nowhere in relation to [our] social condition." ${ }^{36}$ At its best, the utopia is not only an escape from reality, but it points to a new kind of reality. ${ }^{37}$ It expands our sense of reality and reality's possibilities. Other examples Ricoeur provides include Aristotle's portrayal of Greek tragedy, one of the few prior instances of attention in Western thought to the role of productive imagination. For Aristotle, the tragedy is not a copy or reduplication of human life but on the contrary has a "power of disclosure concerning reality." Aristotle's conception of imagination is thus directed against Plato's notion of imagination as a shadow. ${ }^{38}$ Ricoeur also cites Impressionism as another example of productive imagination. Impressionism, he says, created "a new alphabet of colors capable of capturing the transient and fleeting 


\section{RICOEUR'S PHILOSOPHY OF IMAGINATION}

with the magic of hidden correspondences. And once more reality was remade, with an emphasis on atmospheric values and light appearances." ${ }^{39}$ Yet another Ricoeur example, here borrowed from E. $\mathrm{H}$. Gombrich, is landscape painting. The invention of landscape painting was "at the same time for us a new way of looking at nature as a landscape." There was an "augmentation of our world." "Surprisingly, Kant is not particularly helpful in developing Ricoeur's theme of productive imagination's augmentation of reality, as in the First Critique ${ }^{41}$ the role of productive imagination was limited to human understanding of an existing empirical object, ${ }^{42}$ and in the Third Critique ${ }^{43}$ productive imagination was subjective, tied to aesthetic judgments of taste that had no effect on reality. ${ }^{44}$

Ricoeur argues more generally that the "nowhere" not bound by an original can be found in fiction. "Because fictions don't reproduce a previous reality, they may produce a new reality. They are not bound by an original that precedes them." 45 For Ricoeur, three of the four domains of productive imagination - social and cultural imagination (the utopia), epistemological imagination, and poetic imagination come under the rubric of being fictions in this sense. ${ }^{46}$ Having already mentioned the utopia, let me specify the productivity of epistemological and poetic imagination. The fiction in epistemological imagination is the theoretical model that is available in science. A new language is introduced that is then applied to and refigures a domain of application. ${ }^{47}$ An example from Max Black mentioned by Ricoeur is Maxwell's "representation of an electrical field in terms of the properties of an imaginary incompressible fluid." ${ }^{8}$ The application of the model to the "originary domain extends and changes this domain." The model as applied "provides a new description of reality." 49 Similarly, poetic imagination at its best also unfolds new dimensions of reality. It helps us go beyond the world of objects and opens a larger "pre-objective apprehension," a dimension as well the target of Heidegger. ${ }^{50}$ "[M]etaphor is to poetic language what the [theoretical] model is to epistemology." ${ }^{1}$ Both can alter reality.

In his emphasis on fiction as the "nowhere" of social, epistemological, and poetic imagination, Ricoeur certainly understands that this "nowhere" is not totally and absolutely "nowhere," completely uninformed by what has gone before. In fact, he argues against this Romantic view of the imagination. ${ }^{52}$ The productive imagination is "not something irrational," he says; "it must be categorial in order to be transcategorial." ${ }^{53}$ To be effective, the productive imagination must 
transform existing categories; it cannot exist totally outside and separate from them. This suggests that any transformative fiction - any utopia, any scientific model, any poem - must have elements of reproductive imagination, must draw from existing reality sufficiently so that its productive distance is not too great. For example, Impressionism is productive but also, as figurative, still reproductive in part. ${ }^{54}$ Yet the important point remains that productive imagination does introduce a fiction, an image without an original, something from nowhere. Only in this way is it transformative of existing reality.

Part of the great insight and merit of Ricoeur's theory of productive imagination is that it helps both to explain the nature of human creativity and to show its commonality across different spheres, whether that creativity take the form of social, epistemological, or poetic imagination..$^{55}$ Unlike standard approaches to creativity, which either avoid the issue or, as in Karl Popper's work, call "a logic of discovery" what is actually a "logic of verification or falsification of what has been already discovered," ${ }^{56}$ Ricoeur's theory works to unfold the logic of discovery itself. (He does acknowledge that there remains a final element, the "kernel of opacity" that is the transposition itself, that cannot be analyzed. ${ }^{57}$ )

When Ricoeur locates the productive imagination in fiction, in the "nowhere" that fiction provides, the paradox is that fiction provides a new dimension of reality. Unlike Kant, for Ricoeur the productive imagination is "connected with an ontology." If in fiction, says Ricoeur, "we start with an image without an original, then we may discover a kind of second ontology which is not the ontology of the original but ... the ontology displayed by the image itself, because it has no original." ${ }^{, 59}$ Ricoeur's theory of productive imagination requires revision not only of our concept of reality but also of our concept of truth. No longer is truth defined in terms of "adequation," a conformity between judgment and existing reality, because the disclosure of new reality has more to do with a concept of truth as manifestation. ${ }^{60}$

The distinctiveness of Ricoeur's approach to productive imagination is perhaps best established by comparison to the philosophy of Hegel. When Hegel concludes the Preface to his Philosophy of Right, he famously writes that philosophy "appears only when actuality is already there cut and dried after its process of formation has been completed." Like the owl of Minerva, Hegel says, philosophy "spreads its wings only with the falling of the dusk." ${ }^{\prime 1}$ Ricoeur's theory of 


\section{RICOEUR'S PHILOSOPHY OF IMAGINATION}

productive imagination takes a very different stance as it alerts us to disclosure of reality that is both available and yet to come.

Let me conclude with two sets of thoughts, both of which take us beyond the strict confines of the imagination lectures. First, I want to suggest very briefly the nexus between Ricoeur's work on productive imagination and metaphor. Metaphor arises to cross the gap between terms that present a lack of literal fit or common identity. To characterize something metaphorically as "like" something else is, says Ricoeur, "to see the same in spite of, and through, the different." This metaphoric creation of resemblance across difference is also an act of imagination. ${ }^{63}$ "Imagination," Ricoeur writes, "is this ability to produce new kinds of assimilation and to produce them not above the differences, as in the concept, but in spite of and through the differences." ${ }^{\prime 4}$ The imaginative interrelation across difference creates new metaphoric resemblance. ${ }^{65}$

A final set of thoughts responds to the question asking whether productive imagination as a "fiction" opens the way to choices made upon the basis of ideology rather than sound policy or legal determination. How do we distinguish creative from distortive uses of imagination? In the imagination lectures, Ricoeur adverts at points to these concerns. As previously mentioned, he observes that for Spinoza imagination is a matter of illusion and for Pascal it is a matter of sophistry. But these are more incidental remarks in a larger work focused on unfolding productive imagination in its positive sense. It is in his discussion of utopia in the Lectures on Ideology and Utopia that we discover Ricoeur's more complete assessment of both the positive and the negative sides of productive imagination. If the best function of utopia is its "exploration of the possible," 60 its ability to manifest new realities and new truths, the pathology of utopia is its flight into fancy, ${ }^{67}$ its escapism, its turn to the "completely unrealizable," 68 its "magic of thought." ${ }^{69}$ Ricoeur was well aware of the dangers of productive imagination.

And yet Ricoeur does not want to retreat from imagination to the world of reason alone. The good side of productive imagination opens us to much deeper realities and truths. For Ricoeur there remains no bright line to distinguish the good use of productive imagination from the pathological. He addresses the challenge posed here with different vocabulary in various of his works. He calls creative imagination "nothing other than th[e] demand put to conceptual thought . . . to 


\section{GEORGE H. TAYLOR}

think more." ${ }^{70}$ Conceptual thought, in turn, tests the insights of productive imagination: it is reductive; it is elucidative, it seeks clarity. ${ }^{71}$ Elsewhere Ricoeur discusses the balance between understanding and analytic explanation, as through the social sciences. ${ }^{72} \mathrm{He}$ argues analogously in the context of religion that religious testimony too "requires interpretation .... It needs to be tested. .... We must always decide between the false witness and the truthful one for there is no manifestation ... without the threat of a false testimony, and without the decision that separates the sign from the idol." ${ }^{, 73}$ There is a role for judgment. ${ }^{74}$ In the final pages of his Lectures on Ideology and Utopia, Ricoeur concludes that "we cannot eliminate ... the element of risk. We wager on a certain set of values and then try to be consistent with them; verification is therefore a question of our whole life. No one can escape this. Anyone who claims to proceed in a value-free way will find nothing." 75 As I apply Ricoeur's work, then, the claim is that finally we should not restrict ourselves to the settled expectations and boundaries of reproductive imagination. Instead we should recognize, even as we critically assess, the value of the incorporation of productive imagination and the anticipatory and aspirational qualities that such incorporation implies.

University of Pittsburgh

\section{Notes}

${ }^{1}$ Myriam Revault d'Allonnes, "Avant-propos à l'édition française," in Paul Ricoeur, L'Idéologie et l'utopie, trans. Myriam Revault d'Allonnes \& Joël Roman (Paris : Éditions du Seuil, 1997), 13-16, at 13. The book was originally published as Lectures on Ideology and Utopia [Ideology and Utopia], ed. George H. Taylor (New York: Columbia University Press, 1986).

${ }^{2}$ See, e.g., Paul Ricoeur, "The Metaphorical Process as Cognition, Imagination, and Feeling" ["Metaphorical Process"], in On Metaphor, ed. Sheldon Sacks (Chicago: University of Chicago Press, 1979) 141-57; Ricoeur, "The Function of Fiction in Shaping Reality," Man and World 12 (1979): 12341; Ricoeur, "Sartre and Ryle on the Imagination," in The Philosophy of JeanPaul Sartre, ed. Paul A. Schilpp (LaSalle, IL: Open Court, 1981), 167-78; Ricoeur, "Imagination in Discourse and in Action," in From Text to Action, trans. Kathleeen Blamey \& John B. Thompson (Evanston, IL: Northwestern University Press, 1991), 168-87; Ricoeur, "The Bible and the Imagination," in Figuring the Sacred: Religion, Narrative, and Imagination, ed. Mark I. Wallace, trans. David Pellauer (Minneapolis, MN: Fortress Press, 1995), 144-66. On the basis 


\section{RICOEUR'S PHILOSOPHY OF IMAGINATION}

of such limited references, some commentators have developed thoughtful evaluations of Ricoeur's approach to imagination, for example, Jeanne Evans, Paul Ricoeur's Hermeneutics of the Imagination (New York: Peter Lang, 1995); Richard Kearney, "Between Imagination and Language," in On Paul Ricoeur (Burlington, VT: Ashgate, 2004).

${ }^{3}$ Paul Ricoeur, "Lectures on Imagination" (1975) [“Lectures"] (unpublished). As noted, I reviewed transcriptions of the original 1975 course lectures, which were delivered at the University of Chicago. The transcriptions were based on cassette retapings in 1979 of the original reel-to-reel recordings of the 19 course lectures. The original recordings were available at that time at a University of Chicago library. Patrick Crosby undertook the original recording of these lectures (as well as the recording of the Lectures on Ideology and Utopia), and we owe him a considerable debt both for his foresight in anticipating the value of taping these lectures and for his care in making the recordings. In 2003-05, the cassette tapes were initially transcribed by staff at the Document Technology Center at the University of Pittsburgh School of Law, whom I thank for their arduous efforts, and I then listened to the tapes myself in order to edit the transcriptions to ensure their accuracy.

${ }^{4}$ Ricoeur, Ideology and Utopia (op. cit.).

${ }^{5}$ Paul Ricoeur, La métaphore vive (Paris: Éditions du Seuil, 1975). Translated as The Rule of Metaphor: Multi-Disciplinary Studies of the Creation of Meaning in Language [Rule of Metaphor], trans. Robert Czerny (Toronto: University of Toronto Press, 1977).

${ }^{6}$ The three stages of Ricoeur's "Philosophy of the Will" included the following. The first studied the essential - eidetic - structure of human being-in-the world. See Paul Ricoeur, Freedom and Nature: The Voluntary and the Involuntary, trans. Erazim V. Kohák (Evanston, IL: Northwestern University Press, 1966). Originally published as Pbilosophie de la volonté. I. Le volontaire et linvolontaire (Paris: Aubier, 1950). The second stage examined the empirics of actual existence, a stage itself divided into two studies. The first study here was on humanity's existential possibilities (particularly fallibility). See Paul Ricoeur, Fallible Man, trans. Charles Kelbley (Chicago: Henry Regnery Co., 1965). Originally published as Pbilosophie de la volonté. Finitude et Culpabilité. I. L'bomme faillible (Paris: Aubier, 1960). The other volume in this second stage was a study on humanity's actual experiences (in particular, the experience of evil). See Paul Ricoeur, The Symbolism of Evil, trans. Emerson Buchanan (Boston: Beacon Press, 1967). Originally published as Pbilosopbie de la volonté. Finitude et Culpabilité. II. La symbolique du mal (Paris: Aubier, 1960). The third stage, on the poetics of the will, was never formally completed.

${ }^{7}$ Ricoeur, "Lectures," 16:18.

${ }^{8}$ See, for example, Ricoeur's essay "The Bible and the Imagination" in Figuring the Sacred (op. cit.). 


\section{GEORGE H. TAYLOR}

${ }^{9}$ Ricoeur, "Lectures," 2:6, citing J. L. Austin, Sense and Sensibilia (New York: Oxford University Press, 1964).

${ }^{10}$ Ricoeur, "Lectures," 5:10.

${ }^{11}$ Ricoeur, "Lecutres," 9:1.

${ }^{12}$ See Paul Ricoeur, Freud and Philosophy, trans. Denis Savage (New Haven: Yale University Press, 1970).

${ }^{13}$ See, e.g., Paul Ricoeur, The Conflict of Interpretations, ed. Don Ihde (Evanston: Northwestern University Press, 1974), 27-96.

${ }^{14}$ Ricoeur, "Lectures," 7:10. See Jean-Pierre Changeux and Paul Ricoeur, What Makes Us Think? A Neuroscientist and a Philosopher Argue about Ethics, Human Nature, and the Brain, trans. M. B. Debevoise (Princeton, NJ: Princeton University Press, 2000). Ricoeur argues in this book that cognitive science can also not adequately address human creativity.

${ }^{15}$ Ricoeur, "Lectures," 2:1.

${ }^{16}$ Ricoeur, "Lectures," 18:8.

${ }^{17}$ Ricoeur, "Lectures," 3:19.

${ }^{18}$ Ricoeur, "Lectures," 3:7.

${ }^{19}$ Ricoeur, "Lectures," 7:5.

${ }^{20}$ Ricoeur, "Lectures," 7:5.

${ }^{21}$ Ricoeur, "Lectures," 7:14.

${ }^{22}$ Gilbert Ryle, The Concept of Mind (New York: Barnes \& Noble, Inc., 1949), 15.

${ }^{23}$ Ricoeur, "Lectures," 8:11, citing H. H. Price, Thinking and Experience (London: Hutchinson House, 1953).

${ }^{24}$ Ricoeur, "Lectures," 17:8.

${ }^{25}$ Ricoeur, "Lectures," 16:1.

${ }^{26}$ Ricoeur, Lectures, 9:7, citing Ludwig Wittgenstein, Philosophical Investigations, 3d. ed., trans. G. E. M. Anscombe (New York: Macmillan, 1958), 194.

${ }^{27}$ Ricoeur, "Lectures," 9:11.

${ }^{28}$ Ricoeur, "Lectures," 19:18.

${ }^{29}$ Ricoeur, "Lectures," 16:16.

${ }^{30}$ Ricoeur, "Lectures," 14:13, quoting Jean-Paul Sartre, The Psychology of Imagination (New York: Philosophical Library, 1948), 271.

${ }^{31}$ Ricoeur, "Lectures," 13:14.

32 Ricoeur, "Lectures," 14:9.

${ }^{33}$ Ricoeur, "Lectures," 14:13.

${ }^{34}$ Ricoeur, "Lectures," 13:15.

${ }^{35}$ Ricoeur, Ideology and Utopia, 16.

${ }^{36}$ Ricoeur, "Lectures," 14:12.

${ }^{37}$ Ricoeur, "Lectures," 14:19.

${ }^{38}$ Ricoeur, "Lectures," 17:8.

${ }^{39}$ Ricoeur, "Lectures," 17:15. 


\section{RICOEUR'S PHILOSOPHY OF IMAGINATION}

${ }^{40}$ Ricoeur, "Lectures," 17:17, citing E. H. Gombrich, Art and Illusion (Princeton, NJ: Princeton University Press, 1969).

${ }^{41}$ Immanuel Kant, Critique of Pure Reason, trans. Norman Kemp Smith (New York: St. Martin's Press, 1965).

${ }^{42}$ Ricoeur, "Lectures," 5:5.

${ }^{43}$ Immanuel Kant, Critique of Judgment, trans. J. H. Bernard (New York: Hafner Press, 1951).

${ }^{44}$ Ricoeur, "Lectures," 6:7, 6:10.

${ }^{45}$ Ricoeur, "Lectures," 14:19.

${ }^{46}$ Ricoeur, "Lectures," 16:18. The fourth domain of productive imagination - that of religious symbols - is excluded.

${ }^{47}$ Ricoeur, "Lectures," 18:5, citing Max Black, Models and Metaphors (Ithaca, NY: Cornell University Press, 1962).

${ }^{48}$ Ricoeur, "Lectures," 18:5, quoting Black, Models and Metaphors, 226. A more contemporary example of a theoretical model might be string theory in physics. See, e.g., Brian Greene, The Elegant Universe: Superstrings, Hidden Dimensions, and the Quest for the Ultimate Theory (New York: W. W. Norton, 1999).

${ }^{49}$ Ricoeur, "Lectures," 18:6. Note the difference from the description of metaphor in George Lakoff and Mark Johnson where the transfer to a target domain preserves the source domain. "Conceptual metaphor," they write, "allows us to conceptualize one domain of experience in terms of another, preserving in the target domain the inferential structure of the source domain." George Lakoff and Mark Johnson, Pbilosophy in the Flesh: The Embodied Mind and Its Challenges to Western Thought (New York: Basic Books, 1999), 77 (emphasis added). This is reproductive imagination. For Ricoeur, by contrast, productive imagination changes the originary domain.

${ }^{50}$ Ricoeur, "Lectures," 19:12.

${ }^{51}$ Ricoeur, "Lectures," 16:5.

${ }^{52}$ This point is also emphasized by Lakoff and Johnson. For them, the preservation of the source domain in the target domain demonstrates both the origin and continuity of the metaphor. The anti-Romanticist stance in the Lakoff-Johnson line of argument is perhaps most directly stated by Mark Turner: "Originality, far from being autonomous, is contingent at every point upon the unoriginal structures that inform it." Mark Turner, Reading Minds: The Study of English in the Age of Cognitive Science (Princeton, NJ: Princeton University Press, 1991), 51.

${ }^{53}$ Ricoeur, "Lectures," 16:11.

${ }^{54}$ Ricoeur, "Lectures," 17:15.

${ }^{55}$ Ricoeur, "Lectures," 19:1.

${ }^{56}$ Ricoeur, "Lectures," 18:16, citing Karl R. Popper, The Logic of Scientific Discovery (New York, Harper \& Row,1965). 


\section{GEORGE H. TAYLOR}

${ }^{57}$ Ricoeur, "Lectures," 18:20. It is a provocative question that I hope to pursue elsewhere to ask how and how well the productive imagination is incorporated either in theories that treat consciousness as merely the consequence of our biology or in apparently closed theories of linguistic meaning such as Chomsky's. For an initial inquiry, see George H. Taylor, "Cognitive Theory, Conscience, and Law," Graven Images: Studies In Culture, Law, And The Sacred 6 (forthcoming). Along these lines, it is also worth noting that for Ricoeur the space provided by the "nowhere" provides us a freedom from determinism (14:12).

${ }^{58}$ Ricoeur, "Lectures," 19:13.

${ }^{59}$ Ricoeur, "Lectures," 16:1.

${ }^{60}$ Ricoeur, "Lectures," 19:12, 2:20.

${ }^{61}$ G. W. F. Hegel, Philosophy of Right, trans. T. M. Knox (New York: Oxford University Press, 1952), 12-13.

${ }^{62}$ Ricoeur, "Metaphorical Process," 154-55.

${ }^{63}$ Ricoeur, Rule of Metaphor, 196.

${ }^{64}$ Ricoeur, "Metaphorical Process," 146.

${ }^{65}$ I would go on to claim that productive imagination and metaphor help render more precise the generativity of meaning in the famous hermeneutic moment of the application of meaning: the meaning of a principle changes as it is applied. In hermeneutic application, comments Joel Weinsheimer, "the general is . . continually determined by the particular, even as it determines the particular. Application is not reductive but productive ...." Joel C. Weinsheimer, Gadamer's Hermeneutics: A Reading of Truth and Method (New Haven, CT: Yale University Press, 1985), 192 (emphasis added). Application is metaphoric - it creates new resemblance - and is productive a matter of productive imagination.

${ }^{66}$ Ricoeur, Ideology and Utopia, 310.

${ }^{67}$ Ricoeur, Ideology and Utopia, 302.

${ }^{68}$ Ricoeur, Ideology and Utopia, 310.

${ }^{69}$ Ricoeur, Ideology and Utopia, 296.

${ }^{70}$ Ricoeur, Rule of Metaphor, 303.

${ }^{71}$ Ricoeur, Rule of Metaphor, 302-3.

72 See, e.g., Paul Ricoeur, "What is a Text? Explanation and Understanding," in Hermeneutics and the Human Sciences, ed. \& trans. John B. Thompson (Cambridge: Cambridge University Press, 1981), 145-64. I analyze this aspect of Ricoeur's thought at greater length in other work. See George H. Taylor, "Critical Hermeneutics: The Intertwining of Explanation and Understanding as Exemplified in Legal Analysis," Chicago.Kent L aw Review 76 (2000): 1101-23.

${ }^{73}$ Paul Ricoeur, Essays on Biblical Interpretation, ed. Lewis S. Mudge (Philadelphia: Fortress Press, 1980), 112.

\footnotetext{
${ }^{74}$ Ricoeur, Biblical Interpretation, 112.

${ }^{75}$ Ricoeur, Ideology and Utopia, 312.
} 